\title{
The Sustainable Development of the China Pakistan Economic Corridor: Synergy among Economic, Social, and Environmental Sustainability
}

\author{
Muhammad Awais 1(D), Tanzila Samin 2 ${ }^{(0)}$, Muhammad Awais Gulzar ${ }^{3, *(1)}$ and Jinsoo Hwang ${ }^{4, *(1)}$ \\ 1 Department of Data Science \& Engineering Management, School of Management, Zhejiang University, \\ Hangzhou 310058, China; mawaisbal@zju.edu.cn \\ 2 School of Business Management, NFC Institute of Engineering \& Fertilizer Research, Faisalabad 38000, \\ Pakistan; tanzilasaminpk@gmail.com \\ 3 Waikato Management School, The University of Waikato, Hamilton 3240, New Zealand \\ 4 Department of Food Service Management, Sejong University, Seoul 143-747, Korea \\ * Correspondence: awais.gulzar@waikato.ac.nz (M.A.G.); jhwang@sejong.ac.kr (J.H.); \\ Tel.: +8615558031661 (M.A.G.); +82-2-3408-4072 (J.H.)
}

Received: 11 October 2019; Accepted: 3 December 2019; Published: 9 December 2019

\begin{abstract}
This case study focuses on how economic, social and environmental factors synergize for sustainable development, and relates to fundamental speculations, looking to unclutter a query-encompassing view of the China Pakistan Economic Corridor (CPEC). This study is explanatory in nature, and identifies, recognizes, and discusses the social dispositions and fundamental sustainability dimensions related to sustainable development. Three fundamental sustainability dimensions-economic, social and environmental-are incorporated in connection with the CPEC to explore sustainable development. We submit an inclusive viewpoint of the CPEC, towards the sustainable development of economies, from neighborhoods to nations. This explanatory case reveals a momentous sprouting tie between China and Pakistan. For sustainable development in the global context, more meaningful paradigms are needed to be developed. Socio-economic diversity and strategic importance have highlighted a joint perspective and are emerging as novel ways of directing business enterprises to enter the Asian markets, thus contributing to the development and exploitation of operational economic opportunities, leading to competition for the global business market. This study integrates sustainability in connection with the scenario of the CPEC and provides a plethora of understanding.
\end{abstract}

Keywords: China Pakistan Economic Corridor; economic opportunities; environment; sustainable development

\section{Introduction}

The continuous inter-connectedness and integration between cultures, countries, and regions through social and economic systems has consistently advanced the living standards of human societies in absolute and relative terms. Since the mid-19th century, religion, work ethic, migration possibilities, capital flows, free trade, and technological or mechanical development have significantly defined development and growth patterns from cultural, social, economic and technical viewpoints [1].

The China-Pakistan Economic Corridor (hereafter CPEC) is significant to numerous concerns in the connected regions. Since the mid-20th century, trade dealings between China and Pakistan have been improving. In 2005, to enhance integration, both countries launched a free trade accord which was implemented in 2006. Comprised of five sectors of trade deals, the premier is a multi-billion-dollar venture, entailing capital investment, structuring infrastructure, trade promotion, political power, 
and people-to-people exchange programs. The progress of Pakistan through the Belt and Road Initiative (hereafter BRI) led to numerous significant economic and social impacts. The CPEC is beneficial for China, Pakistan and other countries. Furthermore, the primary vision of the CPEC is to supply better communication and transportation, and to improve amalgamation in the global marketplace in a short time frame, in order to advance industrial competitiveness. On the other hand, through industrialization in Pakistan, employment opportunities will be greatly increased in a highly unemployed workforce [2]. Since the 1960s, the Pak-China friendly tie has improved consistently, and now both of the nations are benefiting from solid relationships. In 1972, this friendship was fortified by the construction of the Karakorum Highway (KKH). In terms of regional development and integration, the CPEC is a major development of the BRI and will have a significantly imperative position in the future [3].

'Sustainability' and 'sustainable development' are frequently termed interchangeably. Though sustainable development refers to a process of transformation to achieve sustainability goals [4], the 'ability to sustain' or sustainability [5] defines an end-state that can be sustained over time. Sustainability comprehends the process of sustainable development.

In spite of a widespread review of the literature on the social dimensions of sustainability, there is still no enhanced consideration of the connotation and explanation of sustainable development, particularly while in view of a cross-disciplinary standpoint. Therefore, this study contributes, by discussing and reviewing the ways by which social sustainability is obtainable, from the viewpoint of the sustainable development of the CPEC, in terms of synergy among economic, social and environmental sustainability. In both academic and research circles, interdisciplinary study is appropriate in relation to the CPEC, and it is anticipated that this study will help to explain the disciplinary consideration of the project, and make it possible for both countries to commence the project more efficiently and effectively.

This study comprehends the notion of social sustainability to recognize the core elements of cross-disciplinary fields that contribute to the significance and explanation of sustainability. It has been discovered that economic sustainability is distinguished from environmental sustainability and social sustainability. The broadly recognized description of economic sustainability, as keeping capital integral and maintaining the capital has been used by accountants since the Middle Ages, to permit traders and merchants to know about their deals and let them and their families' power expand without decreasing their capacity to proceed for exchange [6]. The definition of income by Hicks (4S) is 'the quantity an individual can spend during a time period and yet be as affluent at the end of that time period' [6]. Economic sustainability can be defined, as it revolves on consuming interest rather than capital. There are three types of capital: natural, human and social. Since, recently, natural capital had not been scarce, economics has seldom dealt with healthy air and forests. The scarcity of natural capital has gained attention as the level of the human economic subsystem has developed on a large scale compared to its supporting ecosystem $[7,8]$.

Environmental sustainability sustains global life-support systems everlastingly. The source dimensions of worldwide ecosystems deliver water, energy, air, and food; the raw material sink volumes incorporate wastes or yields. These source and sink capacities are great in number but finite, and so sustainability needs to be maintained rather than neglected. Caring for human life is the foremost rationale of anthropocentric humans' search for environmental sustainability. An individual's life depends upon other species for plant pollination, food, breathable air, shelter, waste assimilation, and further environment-sustaining services [6].

The focus of this study not only deals with the sustainable development of the CPEC, but also discusses the synergy among social, economic and environmental sustainability, that provides profound understanding about CPEC.

\section{Sustainable Development}

Economic, environmental and social sustainability dimensions are integrated to formulate sustainable development [6]. The World Wildlife Fund for Nature, 1993, describes sustainable 
development as "The improvement in the quality of human life within the carrying capacity of supporting ecosystems" [6]. The World Commission on Environment and Development (hereafter WCED) explains it thus: "development that fulfills the needs of the current generation without compromising the capability of future to meet up their own needs" [9].

The United Nations adopt sustainable development as a controlling standard for economic, social and environmental growth, that aims to fulfill the requirements without conceding future eras to fulfill their needs, and promote an "impartial allotment of the natural costs and benefits of financial improvement inside and between countries" [10,11]. According to the WCED [12], sustainability demands not only the fortification of environmental and natural assets, but also the supply of the economic and social wellbeing of existing and imminent ancestors. Sustainability has been recognized as a main regulating parameter and standard for a current civilization, that embraces an extended moral association of current and future cohorts $[13,14]$. Sustainability is a centralizing thought, that deliberates economic, environmental and social dimensions as three elementary dimensions, which have been signified as pillars of sustainability required for the contemplation of human, economic capital, and natural resources [15-17].

The perspective of this study is to explore the primary sustainability pillars and to discuss synergies for the imperative objectives of sustainable development. The undertaken three extents of sustainability can have equally positive and negative effects. Synergies have been revealed and examined by scholars and recognized in communal dissertations, e.g., scenic beauty, biodiversity and high environmental quality, allocated for local economic earnings through economical tourism, from which neighborhood communities may profit [18].

\section{China Pakistan Economic Corridor (CPEC)}

The project offers accessibility from China to South Asia, Africa, Europe, and the Middle East through the leading location of the Gwadar port $[19,20]$. China's attentiveness in establishing this project seems to sustain its economic and trade deals with other countries, mainly to tackle its increasing energy necessities and boost exports. It is expected that Pakistan would be strengthened as the center of trade and commerce in the community with the foundation of the CPEC, which would require setting up a number of industrial lands, economic zones, railways and road networks connecting Pakistan and China [3]. The CPEC has extended new opportunities for collaboration, in which regional achievers can acquire the chance of capitalizing their cost-effective interests through the flagship project [21]. Along with the new pattern of regionalism and globalization, the CPEC would also facilitate the strengthening of regional states [22].

With a focus on the sustainable development of the CPEC and the associated economic opportunities, social behavior, and environmental sustainability, this study improves our understanding, by viewing sustainability in terms of the CPEC project. Likewise, no other attempt is being made to conduct research on such a topic.

Although the CPEC is a mutually precious and important venture for both countries, it is of an immediate and direct advantage to China, in allowing for cost-effective shipping to the Middle East as well as Europe [23]. For the shipping of commodities through the CPEC, Pakistan will incur a fee from China [24]. The completion of the CPEC would decrease the distance to 9579 miles, of which 1750 miles will be across land (from Karachi to central China), and 7847 miles will be by sea. Likewise, the required time to transfer the commodities from the existing area to the CPEC itinerary would be lessened by $50-25$ days, which a means $50 \%$ decrease [25]. The lessening in freight of $50 \%-65 \%$ means a 40 feet container reduction from USD 2500 to USD 1000. The consignment to and from the Middle East would also be time-saving and cost-effective in terms of transportation, such that $80 \%$ of the distance would be reduced between central China and the Middle East [26].

The CPEC would offer the most economical course for Afghanistan to the Indian Ocean, India and China. Compared to the adjacent port of Chabahar, the journey would be reduced by about $600 \mathrm{~km}$ [27]. 
If Pakistan facilitates a situation for China to reposition its labor-rich businesses, it would develop further [28]. China has progressively emerged as Pakistan's leading trading and business partner [29].

\section{Sustainability}

\subsection{Economic Sustainability}

The focus of the economic theory is the efficient usage and impartial distribution of goods. Current acknowledgment of the prevalent economic significance of environmental conditions has forced two transformations. Firstly, the new standard of scale must be added to the conventional criterion of efficiency of use and distribution of resources [30,31]. Secondly, markets are perpetually scarce as a distributive system when natural resources are at risk [6]. Economic capital should be stable. The conventional economic criteria of efficiency and allocation must be added as a third of the scale. The scale criteria would confine the flow of energy and material via the human economic subsystem from environmental sources to sinks [32]. In monetary terms, economics values mainly have problems valuing intergenerational, natural capital, intangible, and particularly widespread accessible resources (e.g., air). Because humans are at irreversible risk, economists necessitate the use of protective standards and consciousness of risk and uncertainty [6].

The CPEC is an amalgamation of new energy transportation, roads and railways (infrastructure), and industrial expansion plans. The CPEC's completion will reduce delivery times by 30 days for trade to and from China, ultimately lessening the shipping expenses-whilst staying away from disputed routes (e.g., Indonesia, Taiwan, India Philippines, Vietnam) [33]. Expansion of the Karakorum Highway (hereafter $\mathrm{KKH}$ ) is the critical part of the CPEC, as the single feasible land course between the inland of Pakistan and Kashgar (Shown in Figure 1). Thus, the KKH is anticipated to have a noteworthy upsurge in traffic after the CPEC is completed [34].

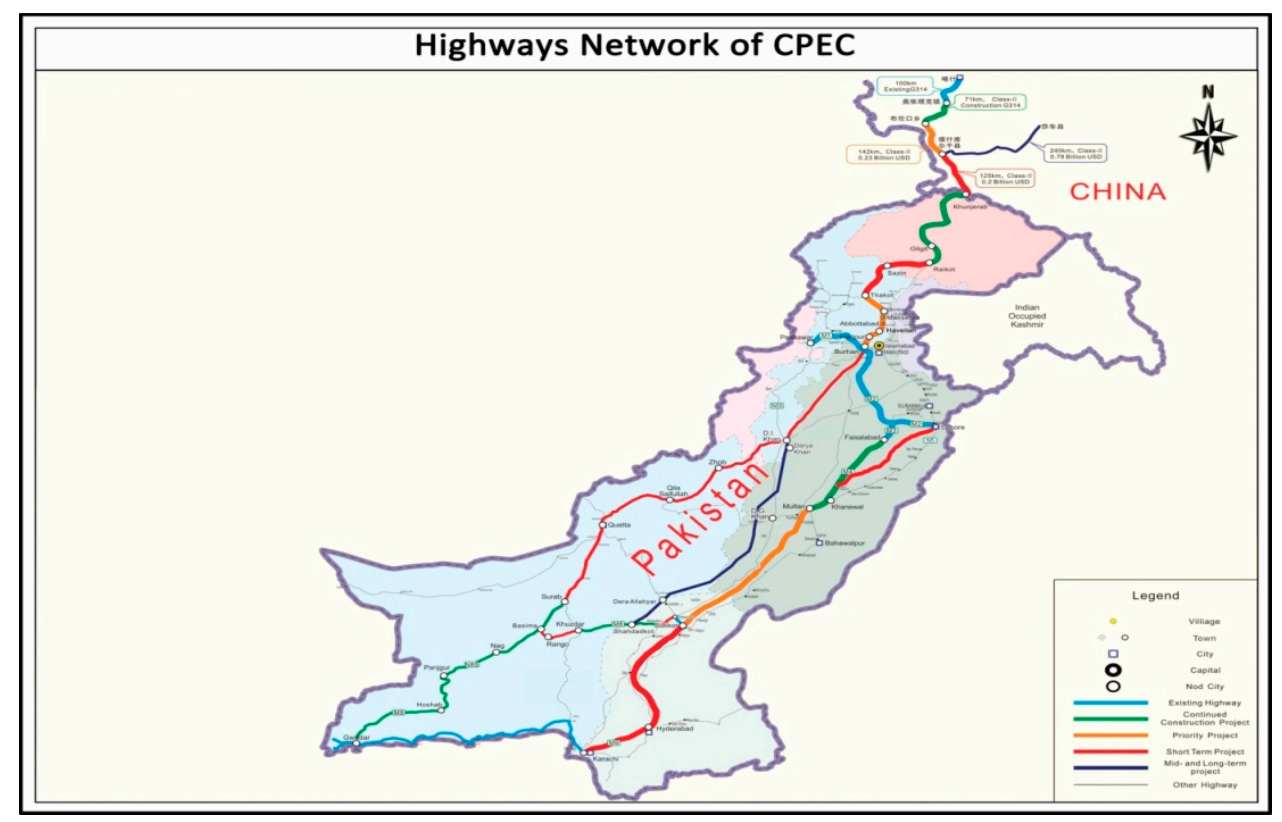

Figure 1. National Highways Network of the CPEC [35].

It is a matter of fact that the CPEC would facilitate trades that were time-saving and cost-effective in terms of transportation, and an improved road and rail network-through which commodities would directly approach China. Furthermore, it would raise services opportunities and increase business competitiveness, thus leading to economic escalation [2]. Around the globe, in the current century, development in global and regional strategies has been directed toward geo-economical and geostrategic corporations amongst countries. The CPEC is one of the paramount examples of such 
partnerships. Through progress in backward and forward linkages, a direct and indirect beneficiary of the CPEC would be the agricultural sector. Agriculture is usually the prime source of employment and income in the countryside. For low-income economies, the agriculture sector serves as the backbone. It is expected that the CPEC would facilitate the enriching of agriculture in Pakistan. The CPEC would prove to be a turning point in economic uplift, leading to an increase in development and production, and a reduction in poverty [36]. Including Pakistan, a third of countries worldwide have experienced an energy disaster that has overwhelmed the industrial sector; decreased agriculture production; led to a drop off in exports and a lack of overseas investment; brought about redundancy, the cease of assistance and an increase in prices for businesses. Most of the textile sector has been shifted out of the country, whereas the remaining industries are shutting down. This disaster has, in turn, led to a high inflation rate and lower Gross Domestic Product (GDP) growth, which consequently leads to an increase in poverty [37]. After suffering for many years, the CPEC offers one prospecting approach to come out of this disaster, through many energy projects [38].

Now Pakistan has a great opportunity to grow as an economic nucleus in the central and South Asian regions. It would uplift economic progress by expanding infrastructure, offering employment chances for masses, and establishing energy and power to develop energy-related projects. It is significant for Pakistan, China, and neighboring countries [37]. Through the CPEC, China's businessmen and private sector will also enter the emergent economy of Pakistan along with the rest of the world. China could benefit, through technological advancement, in the growing, collaborative development of mineral exploration, biological resources, and other areas, to advance China's related industries encouraged by the industrial free-trade zone [39]. For Pakistan and China, the CPEC will offer new opportunities for growth and progress related to tourism and trade. Pakistan is blessed by the most famous valleys and eye-catching Himalayan peaks, including K2. It has stunning deserts, the magnificent Arabian Sea, the glorious Indus Valley, and prehistoric Buddhist culture engraved in its historic forts and mountains. Pakistan is considered to be among the world's supreme tourist destinations. Regrettably, poor infrastructure, a weak tourism framework, low marketing, meager branding, and low government efficacy have affected travel business. Globally, Pakistan is far behind other countries. Through managing the continuing projects and attentively protecting the natural environment as in other countries, Pakistan will be a successful tourist destination [25]. Due to Pakistan being an unstable economy, the CPEC will provide a solution to its tribulations and unlock the latest possibilities of growth and expansion by progressing the socio-economic conditions of the masses and by improving their status. Various unique economic zones are to be developed in Khyber Pakhtunkhwa (KPK), Gilgit-Baltistan, Punjab, Baluchistan, and Sindh. These projects (Shown in Table 1) will ultimately bring prosperity to ventures from prospective international shareholders, and help facilitate Pakistan's economic development [40]. Economic opportunities can be developed for the neighboring countries of Pakistan, including Afghanistan, Iran, and India. If the expected outcomes are achieved, these countries might be willing to take part in the CPEC project. Consequently, this would lessen distrust between South Asian countries. 
Table 1. Projects approved under the CPEC in energy, transport, and infrastructure.

\begin{tabular}{|c|c|c|c|}
\hline CPEC Projects Portfolio & $\begin{array}{c}\text { Phase I (Short-term } \\
\text { 2014-2018) }\end{array}$ & $\begin{array}{c}\text { Phase II (Medium-term } \\
\text { 2014-2030) }\end{array}$ & $\begin{array}{l}\text { Phase III (Long-term } \\
\text { 2014-2030/proposals) }\end{array}$ \\
\hline Infrastructure & $\begin{array}{l}\text { - } 2500 \mathrm{~km} \text { highways } \\
\text { - } 411 \mathrm{~km} \text { railways } \\
\text { - Orange metro line, } \\
\text { Lahore } \\
\text { - Feasibility report of } \\
6600 \mathrm{~km} \text { Railway }\end{array}$ & $\begin{array}{c}\text { - } 3000 \mathrm{~km} \text { highways } \\
\text { - } 1872 \mathrm{~km} \text { railways } \\
\text { - Mass transit, Quetta, } \\
\text { Karachi, Lahore, Peshawar } \\
\text { - Feasibility report of } 5200 \\
\text { km Railway }\end{array}$ & $\begin{array}{c}\text { - } 4000 \mathrm{~km} \text { highways } \\
\text { - } 7000 \mathrm{~km} \text { of new and } \\
\text { upgraded railway } \\
\text { - Road and a railway link } \\
\text { to China, Iran, } \\
\text { Afghanistan, and to } \\
\text { Central Asia and Turkey }\end{array}$ \\
\hline Energy & $\begin{array}{c}\text { - 10,400 MW electricity by } \\
2018 \\
\text { 17,045 MW electricity by } \\
2022 \\
\text { Transmission line } 4000 \\
\text { MW }\end{array}$ & $\begin{array}{c}\bullet 17,045 \text { MW electricity by } \\
2018 \\
\text { - Gwadar-Nawabshah gas } \\
\text { pipeline }\end{array}$ & $\begin{array}{c}\text { - 10,400 MW electricity by } \\
2018 \\
\text { - Gwadar-Kashgar oil } \\
\text { pipeline }\end{array}$ \\
\hline Industry & $\begin{array}{l}\text { - Feasibility study for } 3 \\
\text { Industrial parks }\end{array}$ & $\begin{array}{l}\text { - } 8 \text { Economic Zones } \\
\text { - Steel mills at Gwadar } \\
\text { and Chiniot }\end{array}$ & $\begin{array}{l}\text { - } 39 \text { Economic Zones } \\
\text { - } 21 \text { Mineral processing } \\
\text { units }\end{array}$ \\
\hline Gwadar & $\begin{array}{l}\text { - USD } 1.5 \text { billion in } \\
\text { development Project }\end{array}$ & $\begin{array}{c}\bullet \text { Gwadar port } \\
\text { Gwadar international } \\
\text { airport } \\
\text { Gwadar industrial park } \\
\text { Gwadar city master plan }\end{array}$ & $\begin{array}{c}\text { - Gwadar industrial park } \\
\text { Real estate/housing } \\
\text { schemes }\end{array}$ \\
\hline Other projects & $\begin{array}{l}\text { - Fiber optical cable from } \\
\text { Kashgar to Rawalpindi }\end{array}$ & $\begin{array}{l}\text { - Feasibility study for the } \\
\text { port Keti Bandar }\end{array}$ & $\begin{array}{l}\text { - Fiber optical cable from } \\
\text { Rawalpindi to Karachi } \\
\text { - New cities along CPEC }\end{array}$ \\
\hline Total cost & - USD 46 billion & - USD 54-80 billion & - USD 80-150 billion \\
\hline
\end{tabular}

\subsection{Social Sustainability}

Nowadays, a major restraint on human development is the environment. Primarily significant to social sustainability is the maintenance of life-support systems. Environmental sustainability is a prerequisite for social sustainability, which can only be attained through robust civil society and efficient communal involvement. Cultural identity, unity of community, comity, compassion, forbearance, fellowship, fraternity, diversity, humility, sodality, tolerance, patience, love, institutions and pluralism, and the generally acknowledged values of discipline, honesty and laws, etc., comprise the element of social capital subject to careful measurement, but essential for social sustainability. This "moral capital" entails replenishment and maintenance of equal rights and shared values through societal, cultural and religious interactions. Exclusive of this concern, it will devalue physical capital. Human capital reserves in health, nutrition, and the education of individuals are now acknowledged as part of economic development [6].

\subsection{Environmental Sustainability}

The concept of economic sustainability was decisively personified by the researchers [41-43]. Mill [41] highlighted that the environment/nature needs to be sheltered from unregulated expansion if we are to protect human wellbeing before it is too late.

The means of production established in many portions of the world are aggravating the causes of the collapse and the dispersal of the one-time legacy of groundwater, fisheries, tropical forests, topsoil, and biodiversity. The swift exhaustion of vital resources, the atmospheric quality, and the degradation of land confirm that the human economy is imposing severe harm on supporting ecosystems globally, and prospective biophysical haulage capacities are most likely being reduced [44,45].

The international distribution of overseas investment not only supports economic growth, but also transfers its environmental risks to the host states. Further financial support and sustainable 
developmental paths are required for novel technologies that are less energy-intensive, and renewable energy should also be implemented [46]. Three out of seven of the world's biggest glaciers are located in Northern Pakistan. There are 5218 glaciers (extending to a region of about 15,040 km²), and snow covers $2738 \mathrm{~km}^{3}$. Unfortunately, due to a number of global warming and anthropogenic actions, these glaciers are melting day by day [47]. Around 7000 trucks will pass through this area on a daily basis due to the CPEC project and release more than 36.5 million tons of $\mathrm{CO}$. Such a release will relentlessly trim down the glaciers and will possibly result in the severe over-flow of water [48]. While in other areas at the same time, due to water scarcity, some sectors will be affected badly, including agriculture, food production for the increasing population, water-based operating industries, and hydroelectricity generation. A deteriorated natural environment, the massive scaling of the glaciers and changes in patterns caused by massive traveling through the CPEC route will distress biodiversity [49]. It will severely influence the aquatic biodiversity on the coastline of the Gwadar Port, the Arabian Sea and Pakistan. Due to the latest global warming trends, the areas beside the CPEC routes are extremely sensitive to climatic changes [50-52].

\section{Conclusions}

This study presents the sustainable development of the CPEC as shown in Figure 2, discussing synergy among elements of economic, social and environmental sustainability. The case deals with the immense challenge of ensuring that the CPEC provides economic opportunities without damaging the environment on which we all depend. To achieve the goals of economic and social sustainability, environmental sustainability must be considered during the completion of the project.

The CPEC is anticipated to be a win-win project. Pakistan and China both will benefit from investment in the energy, construction, and infrastructure sectors under the CPEC, from social and economic resources, and other projects. It is a long-term venture and will impact the area for a long period. The construction and investment projects entail several aspects affecting individuals, the community, and social development [53]. The CPEC comprises the system of expansion of infrastructure, so politicians, and individuals from all walks of life, should support the CPEC at every level.

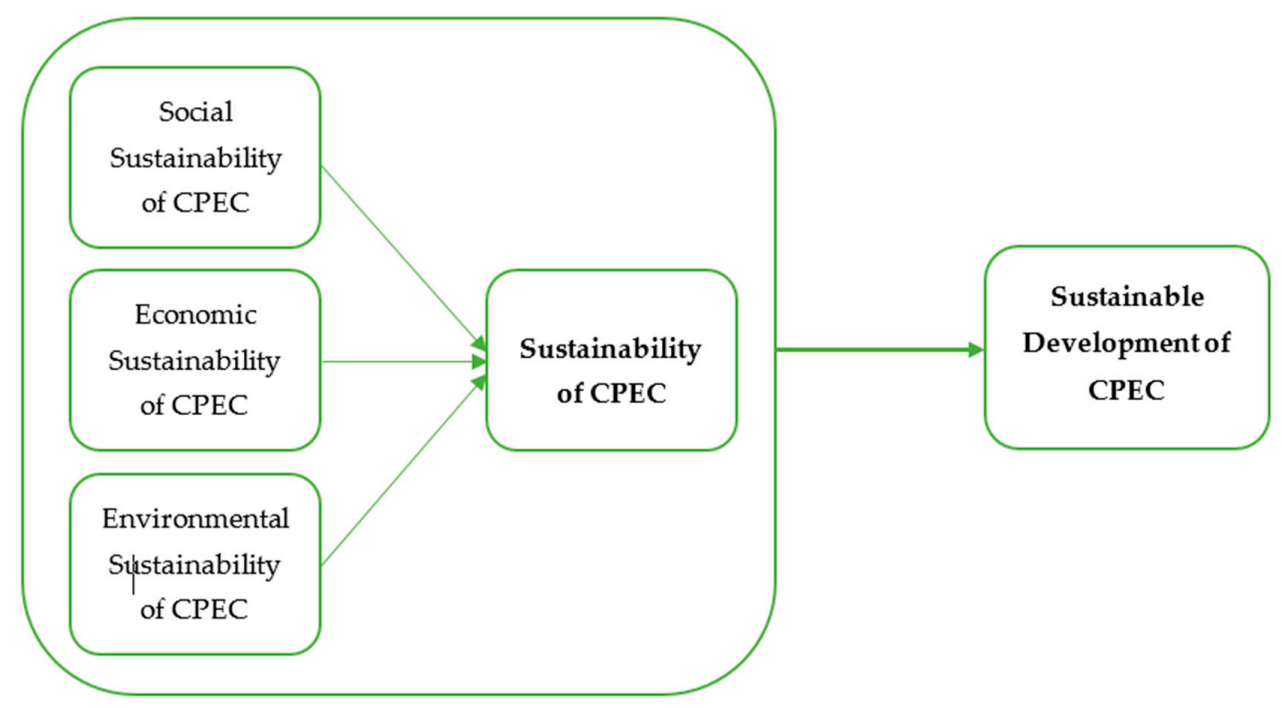

Figure 2. Proposed synergy model for sustainable development (CPEC).

To promote sustainability, businesses are at a vital point and being held accountable for the communal impact that results from their activities (economic, social and environmental) [54]. Concerns regarding sustainability have been raised by practitioners, researchers and academics, augmenting the stakeholder's consciousness of social and environmental concerns. None of the previous studies 
have focused on the sustainable development of the CPEC, or its synergy among economic, social and environmental sustainability.

The country should look favorably on the completion of this mega project [36]. Amongst the South Asian countries, due to the current development of the CPEC, Pakistan has become the first transit hub for the world's most successful and leading economy [55]. To give complete support to the overseas workforce of the CPEC project, the government is required to be very dynamic. For both China and Pakistan, the CPEC is a game-changing project. It is a road link (2000 km) between Gwadar port (and the Arabian Sea) and Kashgar, which will be revolutionary, both geopolitically and geographically. Due to this grand project, a number of opportunities can be expected, as oil will be imported at inexpensive rates by connecting the Gulf countries, and will be transferred to China by crossing Karakoram and Baluchistan.

\section{Recommendations and Future Directions}

There is an imperative desire for planning, supervising and administrating against environmental threats and biodiversity-related matters by dedicated scientists and experts from both countries. Moreover, to decrease the release of carbon, electric automobiles should be used as a substitute for oil-based automobiles, and the consequential unsafe waste from these automobiles should be managed and disposed of cautiously, to maintain an environmentally friendly corridor [56].

During the tunnel construction, blasting should be avoided and drilling methods should be used. Engraving and filling up should be balanced, and digging out materials should be utilized as filtering structures. Waste material should be disposed of at approved and designated spots. Windrows and trenches should be used to reduce surface contaminated and polluted runoff. Spills and leaks from construction vehicles and equipment should be prevented by regular checking and repairing, especially of those driving near water bodies. To decrease dust and particulate matter, emanation water sprinklers should be used. On an immediate basis, plantation along the roadside should be conducted. The installation of noise barriers and wildlife corridors should be made compulsory. To minimize transporting and transportation distances, and decrease emissions to the environment and save energy, all procurements should be either made locally or from nearby industries. Along the CPEC, roads and routes should preferably be constructed far away from the agricultural areas, water resources, and forests. Steep slopes and highly erodible soils that are exposed to wind and water erosion, the clearance of trees, forests and cultivated areas should be minimized and possibly avoided. Plantation should be completed quickly, as each sector of the project is accomplished, reducing the gap between clearing and planting to the least possible time [57]. Decisions should be made for a short-term solution to CPEC energy ventures that are in process. There are efficient, small-scale and short-term solutions to deal with the energy crisis. The key solution is the readily accessible resource of the sun-because of the main geographical location, safety, environmental health, lower maintenance cost, and minor political involvement. If explored and exploited appropriately, the CPEC can overcome the two-decade-old problem of a deficit in energy, whilst uplifting the socio-economic structure of the country [37].

Without three main elements-transparency, accountability, and the extensive contribution of the community through information flow-it is impossible to accomplish environmental protection and sustainable development [58]. The third aspect entails the accessibility of a communication tool that facilitates the diffusion of information, to decrease the knowledge/informational deficiency that is linked to dreadful environmental conditions. As a tool for environmental management, communication has often been ignored as an element of environmental ascendancy, and there are gaps in the accessible literature [59]. To fill this gap, future study will be conducted. Above all, the CPEC has emerged to be a blessing for the countries involved [60].

Author Contributions: M.A. contributed to the literature review, the conceptualization and writing of the original article, and prepared the final draft. T.S. contributed in the conceptualization and research design, M.A.G. contributed in the conceptualization, editing and revision, and J.H. contributed in revision. All the authors approved the final manuscript. 
Funding: This research received no external funding.

Acknowledgments: We are thankful to the School of Management, Zhejiang University for academic and research assistance and all the teachers for their guidance and support.

Conflicts of Interest: The authors declare that they have no conflict of interest.

\section{References}

1. Coulibaly, S.K.; Erbao, C.; Mekongcho, T.M. Economic globalization, entrepreneurship, and development. Technol. Forecast. Soc. Chang. 2018, 127, 271-280. [CrossRef]

2. Naz, L.; Ali, A.; Fatima, A. International competitiveness and ex-ante treatment effects of CPEC on household welfare in Pakistan. Int. J. Dev. Issues 2018, 17, 168-186. [CrossRef]

3. Irshad, M.S.; Xin, Q.; Arshad, H. One Belt and One Road: Dose China-Pakistan Economic Corridor Benefit for Pakistan's Economy? J. Econ. Sustain. Dev. 2015, 6, 200-207. Available online: https: //iiste.org/Journals/index.php/JEDS/article/view/27923/29916 (accessed on 5 September 2019).

4. Weingaertner, C.; Moberg, Å. Exploring social sustainability: Learning from perspectives on urban development and companies and products. Sustain. Dev. 2014, 22, 122-133. [CrossRef]

5. Marcuse, P. Sustainability is not enough. Environ. Urban. 1998, 10, 103-112. [CrossRef]

6. Goodland, R. The concept of environmental sustainability. Annu. Rev. Ecol. Syst. 1995, 26, 1-24. [CrossRef]

7. Daly, H.E. The Economics of the Steady State. Am. Econ. Rev. 1974, 64, 15-21. Available online: http://www.jstor.org/stable/1816010 (accessed on 7 September 2019).

8. Daly, H.E.; Cobb, J.B., Jr.; Cobb, J.B. For the Common Good: Redirecting the Economy toward Community, the Environment, and a Sustainable Future; Beacon Press: Boston, MA, USA, 1994.

9. Brundtland, G.; Khalid, M.; Agnelli, S.; Al-Athel, S.; Chidzero, B.; Fadika, L.; Hauff, V.; Lang, I.; Shijun, M.; de Botero, M.M. Our Common Future ( $\left({ }^{\prime}\right.$ Brundtland Report $\backslash^{\prime}$ ); Oxford University Press: Oxford, UK, 1987.

10. Carroll, A.B. Corporate social responsibility: Evolution of a definitional construct. Bus. Soc. 1999, 38, $268-295$. [CrossRef]

11. United Nations. UN General Assembly Resolution 42/187. Report of the World Commission on Environment; United Nations: New York, NY, USA, 1987.

12. Wced, S.W.S. World commission on environment and development. In Our Common Future; Brundtland Report; Oxford University Press: Oxford, UK, 1987.

13. Laws, D.; Scholz, R.W.; Shiroyama, H.; Susskind, L.; Suzuki, T.; Weber, O. Expert views on sustainability and technology implementation. Int. J. Sustain. Dev. World Ecol. 2004, 11, 247-261. [CrossRef]

14. Scholz, R.W. Environmental Literacy in Science and Society: From Knowledge to Decisions; Cambridge University Press: Cambridge, UK, 2011.

15. Elkington, J. Cannibals with Forks: The Triple Bottom Line of 21st Century Business; Wiley: Hoboken, NJ, USA, 1997.

16. Kajikawa, Y. Research core and framework of sustainability science. Sustain. Sci. 2008, 3, 215-239. [CrossRef]

17. Schoolman, E.D.; Guest, J.S.; Bush, K.F.; Bell, A.R. How interdisciplinary is sustainability research? Analyzing the structure of an emerging scientific field. Sustain. Sci. 2012, 7, 67-80. [CrossRef]

18. Gurung, D.B.; Scholz, R.W. Community-based ecotourism in Bhutan: Expert evaluation of stakeholder-based scenarios. Int. J. Sustain. Dev. World Ecol. 2008, 15, 397-411. [CrossRef]

19. Ahmar, M. Strategic Meaning of China-Pakistan Economic Corridor Strategic Meaning of the China-Pakistan Economic Corridor. Strateg. Stud. 2016, 34, 35-49.

20. Chaziza, M. China-Pakistan relationship: A game-changer for the Middle East? Contemp. Rev. Middle East. 2016, 3, 147-161. [CrossRef]

21. Chawla, M.I. One Belt One Road Summit 2017 and its Implications for CPEC: An Overview. South Asian Stud. 2017, 32, 277-284.

22. Khetran, M.S.B.; Saeed, M.A. The CPEC and China-Pakistan relations: A case study on Balochistan. China Q. Int. Strateg. Stud. 2017, 3, 447-461. [CrossRef]

23. Bhutta, Z. Gwadar Port: Pakistan, China all set to develop master plan. The Express Tribune 2014. Available online: https:/tribune.com.pk/story/671852/gwadar-port-pakistan-china-all-set-to-develop-master-plan/ (accessed on 9 September 2019). 
24. Vélez, F. From the Suez to the Panama Canal and Beyond: Gamal Abdel Nasser's influence in Latin America. Varia Hist. 2015, 31, 163-191. [CrossRef]

25. Ali, S.A.; Haider, J.; Ali, M.; Ali, S.I.; Ming, X. Emerging Tourism between Pakistan and China: Tourism Opportunities via China-Pakistan Economic Corridor. Int. Bus. Res. 2017, 10, 204-214. [CrossRef]

26. Hao, H.; Geng, Y.; Li, W.; Guo, B. Energy consumption and GHG emissions from China's freight transport sector: Scenarios through 2050. Energy Policy 2015, 85, 94-101. [CrossRef]

27. Lin, W.; Chen, B.; Xie, L.; Pan, H. Estimating energy consumption of transport modes in China using DEA. Sustainability 2015, 7, 4225-4239. [CrossRef]

28. Shaikh, F.; Ji, Q.; Fan, Y. Prospects of Pakistan-China energy and economic corridor. Renew. Sustain. Energy Rev. 2016, 59, 253-263. [CrossRef]

29. Holtom, P.; Bromley, M.; Wezeman, P.D.; Wezeman, S.T. Trends in International Arms Transfers, 2012; Stockholm International Peace Research Institute: Stockholm, Sweden, 2013.

30. Daly, H.E. Allocation, distribution, and scale: Towards an economics that is efficient, just, and sustainable. Ecol. Econ. 1992, 6, 185-193. [CrossRef]

31. Opschoor, J.B. Environment, Economy, and Sustainable Development; Wolters-Noordhoff Publishers: Groningen, The Netherlands, 1992.

32. Daly, H.E. Toward some operational principles of sustainable development. Ecol. Econ. 1990, 2, 1-6. [CrossRef]

33. Chowdhary, M. China's Billion-Dollar Gateway To The Subcontinent: Pakistan May Be Opening A Door It Cannot Close. 2015. Available online: https://www.forbes.com/sites/realspin/2015/08/25/china-looks-topakistan-to-expand-its-influence-in-asia/\#5ad410ba3de9 (accessed on 13 September 2019).

34. Sareen, S. Corridor Calculus: China Pakistan Economic Corridor E China's Comprador Investment Model in Pakistan; Vivekananda International Foundation: New Delhi, India, 2016.

35. China Pakistan Economic Corridor. China Pakistan Economic Corridor (CPEC). 2018. Available online: http://cpec.gov.pk/maps (accessed on 1 September 2019).

36. Ahmed, R.; Mustafa, U. Impact of CPEC Projects on Agriculture Sector of Pakistan: Infrastructure and Agricultural Output Linkages. Pak. Dev. Rev. 2017, 56, 511-528.

37. Ali, Y.; Rasheed, Z.; Muhammad, N.; Yousaf, S. Energy optimization in the wake of China Pakistan Economic Corridor (CPEC). J. Control Decis. 2018, 5, 129-147. [CrossRef]

38. Stevens, A. Pakistan lands $\$ 46$ billion investment from China. CNN Money 2015. Available online: https://money.cnn.com/2015/04/20/news/economy/pakistan-china-aid-infrastucture/ (accessed on 15 September 2019).

39. Irshad, M.S.; Xin, Q. A New Perspective of the China-ASEAN Free Trade Area and the Story of Top Ten Products. Eur. J. Bus. Manag. 2014, 6, 1-8. Available online: https://iiste.org/Journals/index.php/EJBM/article/ view/13640/13861 (accessed on 5 September 2019).

40. Butt, K.M.; Butt, A.A. Impact of CPEC on Regional and Extra-Regional Actors. J. Political Sci. 2015, 33, $23-44$.

41. Mill, J.S. Principles of Political Economy; Colonial Press: New York, NY, USA, 1900; Volume 2.

42. Malthus, T.R. Principles of Political Economy Considered with a View to Their Practical Application; Kelley: London, UK, 1964; 446p.

43. Malthus, T.R. An. Essay on the Principle of Population and a Sumary View of the Principle of Population; J. Johnson: London, UK, 1798; p. 291.

44. Daily, G.C.; Ehrlich, A.H.; Ehrlich, P.R. Optimum human population size. Popul. Environ. 1994, 15, 469-475. [CrossRef]

45. Daily, G.C.; Ehrlich, P.R. Population, sustainability, and Earth's carrying capacity. BioScience 1992, 42, 761-771. [CrossRef]

46. Zubedi, A.; Zeng, J.; Arain, Q.A.; Memon, I.; Khan, S.; Khan, M.S.; Zhang, Y. Sustaining Low-Carbon Emission Development: An Energy Efficient Transportation Plan for CPEC. J. Inf. Process. Syst. 2018, 14, 322-345. [CrossRef]

47. Syed Naseem Abbas, G.; Javed, I. Geospatial analysis of glacial hazard prone areas of Shigar and Shayok basins. Int. J. Innov. Appl. Stud. 2016, 14, 623-644. Available online: https://search.proquest.com/ openview/e3357b16198f0ad12d17be70f3acd70f/1.pdf?pq-origsite=gscholar\&cbl=2031961 (accessed on 5 September 2019). 
48. Laghari, J. Climate change: Melting glaciers bring energy uncertainty. Nat. News 2013, 502, 617-618. [CrossRef] [PubMed]

49. Nabi, G.; Khan, S.; Ahmad, S.; Khan, A.; Siddique, R. China-Pakistan Economic Corridor (CPEC): An alarming threat to the biodiversity of Northern Pakistan. Biodivers. Conserv. 2017, 26, 3003-3004. [CrossRef]

50. Asmat, U.; Athar, H.; Nabeel, A.; Latif, M. An AOGCM based assessment of interseasonal variability in Pakistan. Clim. Dyn. 2018, 50, 349-373. [CrossRef]

51. Iqbal, M.F.; Athar, H. Validation of satellite based precipitation over diverse topography of Pakistan. Atmos. Res. 2018, 201, 247-260. [CrossRef]

52. Yamada, T.J.; Takeuchi, D.; Farukh, M.; Kitano, Y. Climatological characteristics of heavy rainfall in northern Pakistan and atmospheric blocking over western Russia. J. Clim. 2016, 29, 7743-7754. [CrossRef]

53. Zhang, R.; Shi, G. Social impacts assessment for China-Pakistan economic corridor investment activities. Energy 2016, 33, 76. [CrossRef]

54. Elkington, J. Partnerships from cannibals with forks: The triple bottom line of 21st-century business. Environmental quality management 1998, 8, 37-51. [CrossRef]

55. Nilofar, M.; Jiang, W.S.; Ishtiaque, M. The growing economic ties between Pakistan and china and its impact on the economy of Pakistan. Impact Int. J. Res. Humanit. Arts Lit. 2014, 2, 49-54.

56. Nabi, G.; Ullah, S.; Khan, S.; Ahmad, S.; Kumar, S. China-Pakistan Economic Corridor (CPEC): Melting glaciers-A potential threat to ecosystem and biodiversity. Environ. Sci. Pollut. Res. 2018, 25, 3209-3210. [CrossRef] [PubMed]

57. Khwaja, M.A.; Saeed, S.; Urooj, M. Preliminary Environmental Impact Assessment (EIA) Study of China-Pakistan Economic Corridor (CPEC) Northern Route Road Construction Activities in Khyber Pakhtunkhwa (KPK), SDPI Pakistan. 2018. Available online: http://www.esocialsciences.org/Download/ repecDownload.aspx?fname=A2018628151510_29.pdf\&fcategory=Articles\&AId=12846\&fref=repec (accessed on 3 September 2019).

58. Chemutai, B. Achieving Effective National Environmental Governance in Africa. Iss Today. 2009. Available online: https://issafrica.org/iss-today/achieving-effective-national-environmental-governance-in-africa (accessed on 3 September 2019).

59. Asongu, S.A.; Le Roux, S.; Biekpe, N. Enhancing ICT for environmental sustainability in sub-Saharan Africa. Technol. Forecast. Soc. Chang. 2018, 127, 209-216. [CrossRef]

60. Ebrahim, Z. China Pakistan Economic Corridor: A Boon for the Economy, a Bane for Locals. 2016. Available online: https://www.dawn.com/news/1236159 (accessed on 11 September 2019). 